\title{
SLOVENIJA IN OBLIKOVANJE SONARAVNE RAZVOJNE STRATEGIJE EVROPSKE ZVEZE
}

\author{
Dušan Plut*
}

\section{Izvleček}

UDK 911.3:504.03=863(4-15:497.4)

Zaradi okoljskih in razvojnih razlogov je Evropska zveza v prvi polovici 90. let oblikovala nov akcijski okoljski program, ki izhaja iz paradigme sonaravnega razvoja. V članku so predstavljeni okoljski cilji, temeljne sestavine in instrumenti sonaravnega okoljskega programa EZ ter problematika prilagajanja Slovenije evropskim okoljsko - razvojnim trendom.

Ključne besede: Evropska zveza, sonaravna razvojna strategija, instrumenti okoljske politike, okoljski akcijski program

\section{SLOVENIA AND THE FORMATION OF SUSTAINABLE DEVELOPMENTAL STRATEGY OF THE EUROPEAN UNION}

\section{Abstract}

Due to the environmental and developmental reasons, the European Union formed a new active environmental programme in the first half of the nineties, which proceeds from the paradigm of sustainable development. Presented are the environmental aims, basic components and instruments of sustainable environmental programme of the EU and the problems of adapting Slovenia to European environmental-developmental trends.

Key words: European Union; Sustainable developmental strategy; Instruments of environmental policy; Active environmental programme.

\footnotetext{
"Dr., izr. prof., Oddelek za geografijo, Filozofska fakulteta Univerze v Ljubljani, Aškerčeva 2, SI 1000 Ljubljana, Slovenija
} 


\section{EVROPA IN SODOBNI RAZVOJNO - OKOLJSKI TRENDI}

V prepletu sodobnih civilizacijskih pritiskov lokalne, regionalne in globalne ravni tudi obstoječi zahodnoevropski družbenogospodarski model ne odgovarja sodobnim izzivom, ki jih zarisujejo globalizacijski in regionalizacijski procesi. Silnice ekonomskih, socialnih in okoljskih procesov se prepletajo, sektorsko zasnovani pristopi in razvojne strategije so prinesli le kratkotrajne rešitve posamičnega problema, navadno na račun poslabšanja na enem ali več ostalih družbenih poljih. Zlasti v Evropski zvezi (EZ) je v 90. letih prisotno zahtevno, inovativno zasnovano iskanje primernejšega evropskega družbenega modela, katerega skrajnosti predstavljata neoliberalistična, ozko tržno zasnovana gospodarska strategija na eni, ter model maksimalne ekosocialne blaginje na drugi strani, ki podcenjuje tržne zakonitosti. V širokem vmesnem polju obstajajo številni modeli družbenega razvoja, vključno $\mathrm{z}$ različnimi inačicami sonaravnega razvoja, ki tržno zasnovan gospodarski napredek postavlja $\vee$ čvrste okoljske in socialne okvire ter odgovornost do bodočih generacij (ohranjanje bioloških pogojev življenja, visoka stopnja zaposlenosti, socialna zaščita). Vrsta znanstvenikov sodi, da so 90 . leta morda zadnja priložnost za pričetek spreminjanja usmerjenosti svetovnih okoljskih procesov $\mathrm{v}$ smeri sonaravnega razvoja (Atlas of the Environment, 1990).

Države EZ se sredi 90 . let soočajo s tremi temeljnimi družbenimi problemi: visoko brezposelnostjo (20 milijonov brezposelnih le v državah Evropske zveze), krizo obstoječega načina socialne zaščite in dolgotrajnim izčrpavanjem naravnih virov ter človekovega okolja. Tudi gospodarsko razvitejši del Evrope čaka odgovorna naloga pomoči posocialističnim evropskim državam (tudi v lastnem interesu), hkrati pa trdo tržno tekmovanje, zlasti $\mathrm{s}$ severnoameriškim gospodarstvom in industrijskimi "gazelami" držav ekonomsko vzhajajočega pacifiškega loka. Države EZ so še vedno med največjimi planetarnimi onesnaževalci in porabniki naravnih virov, obenem pa postajajo eden najbolj pomembnih nosilcev naravi in okolju prijaznejšega gospodarskega in regionalnega razvoja ter pobudnikov udejanjanja sonaravne civilizacijske paradigme (Europe's Environment, 1995). Okoljsko polje postaja eno izmed osrednjih polj evropskih integracijskih procesov, ki so se na področju težke industrije in kmetijstva pričeli že v 50 . letih. EZ pomeni sredi 90 . let torej vse tesnejšo povezanost evropskih držav in narodov $\mathrm{v}$ okviru enotnega notranjega trga s prostim pretokom dobrin, storitev, prebivalcev in informacij ter še vedno dokaj previdnim pričetkom iskanja poti za trajen, uravnotežen in varnejši gospodarski, socialni in okoljski napredek. 


\section{AKCIJSKI OKOLJSKI PROGRAM EZ (1993 - 2000)}

Zaradi planetarnega in regionalnega negativnega okoljskega vpliva proizvodnje in potrošnje ter določenega razvojnega zaostajanja držav EZ je bilo potrebno v 90.letih izdelati bistveno drugačen, celostno zasnovan okoljski program. Maastrichtski sporazum (1.1992) je razglasil nujnost povezave varstva okolja in drugih politik EZ, zato je bil sprejet 5. akcijski okoljski program (1993 - 2000), ki izhaja iz načel trajnostnega sonaravnega razvoja (Towards Sustainability, 1993). 5. akcijski program za varstvo okolja pomeni za EZ preokret, zasnovan na priporočilih Agende 21 (OZN) iz 1. 1992. Razen prevladujočih zakonskih instrumentov se uvaja uporaba davčnih, gospodarskih in finančnih okoljskih instrumentov ter širše odpira pot do okoljskih informacij in izobraževanja. Okoljska strategija podpira dogovarjanje, skupno delo z nacionalnimi, regionalnimi in lokalnimi organi, predstavniki gospodarstva in prebivalci (Gemeinschaftsrecht im Bereich...,1996). Okoljska strategija postavlja v ospredje naslednja akcijska polja oziroma zahteve (Towards Sustainability, 1993, s.56):

- sonaravno upravljanje z naravnimi viri: prst, voda, naravna območja in obalna območja;

- integrirano premagovanje onesnaževanja okolja in ukrepe preprečevanja pri gospodarjenju z odpadki;

- zmanjšanje porabe neobnovljivih energijskih virov;

- izboljšanje na območju mobilnosti, zlasti z okolju primernejšim izborom lokacij za podjetja in pri prometnih sredstvih;

- izboljšanje zdravja in varnosti, zlasti glede industrijskih tveganj, jedrske varnosti in zaščite pred žarčenjem.

Peti okoljski program EZ obsega širok izbor okoljskih polj: spremembe podnebja, zakisovanje in onesnaževanje zraka, izkoriščanje naravnih virov, zmanjševanje pestrosti vrst, izčrpavanje in onesnaževanje vod, uničevanje mestnega okolja in obalnih območij ter odpadke. Na nivoju Zveze so v ospredju obravnave gospodarsko širše okoljske razsežnosti, ki so povezane s skupnim trgom, prekomejnimi okoljskimi problemi, skupno uporabo naravnih virov ter posebej pomembnimi regijami $\mathrm{z}$ vidika kakovosti okolja (Gemeinschaftsrecht im Bereich...,1996). 5. okoljski program EZ natančno opredeljuje okoljske cilje, časovne okvire, nosilce, instrumente in prednostna okoljska polja. Konkretni okoljski cilji Zveze so naslednji (Towards Sustainability, 1993):

1. stabilizacija emisij ogljikovega dioksida (CO2) do 1. 2000 in pospešeno zmanjševanje do 1. 2010;

2. zmanjšanje emisij dušikovih oksidov (NOx) za $30 \%$ do 1.2000 v primerjavami z emisijami v 1. 1990;

3. zmanjšanje emisij žveplovega dioksida (SO2) za $35 \%$ do 1.2000 v primerjavi z emisijami 1. 1985; 
4. zmanjšanje emisij VOC (hlapne organske spojine) za $30 \%$ do 1.1999 v primerjavi z emisijami 1. 1990;

5. zmanjšanje emisij dioksina za $90 \%$ do 1.2005 v primerjavi z emisijami 1. 1985;

6. ohranjanje biološke raznovrstnosti s pomočjo sonaravno zasnovanega razvoja, upravljanjem naravnih habitatov in kontrolo mednarodne trgovine $\mathrm{z}$ divjimi vrstami; 7. sonaravna raba virov sveže vode (ravnovesje med porabo in zmogljivostjo vodnih virov), ohranjanje in izboljšanje kakovosti vode s pomočjo integriranega vodnega upravljanja;

8. do 1. 2000 odprava izpostavljenosti nočnemu hrupu, ki presega $65 \mathrm{~dB}$;

9. sonaravni razvoj obalnih območij v okviru nosilnosti obalnih ekosistemov;

10. stabilizacija letne količine komunalnih odpadkov do 1.2000 na višini 300 $\mathrm{kg} /$ prebivalca;

11. reciklaža ali ponovna uporaba vsaj $50 \%$ papirja, stekla, plastike do 1. 2000;

12. odprava izvoza nevarnih odpadkov do 1. 2000;

13. $50 \%$ zmanjšana uporaba vretenčarjev do 1.2000 pri poskusih na živalih;

14. izboljšanje jedrske varnosti in razširitev uporabe strogih standardov jedrske varnosti do 1. 2000 v vse posocialistične evropske države (vključno z Rusijo).

\section{PREDNOSTNA POLJA OKOLJSKE POLITIKE EZ}

5. akcijski okoljski program EZ (1993 - 2000) izhaja iz prepričanja, da je temeljni vzrok okoljskih problemov in izčrpavanja naravnih virov pravzaprav obstoječi, nesonaravni vzorec potrošnje in potrošniško obnašanje. Zgolj sprememba načina proizvodnje in potrošnje nudi realne možnosti za dosego okoljskih in ostalih ciljev EZ. V programu je izbranih 5 prednostnih polj okoljskega delovanja: industrija, energija, promet, kmetijstvo in turizem (Towards Sustainability, 1993). Prednostna polja so bila izbrana zaradi posebno močnega vpliva izbranih dejavnosti na okolje kot celoto, odpravljanje okoljskih problemov v ključnih gospodarskih poljih pa bi pospešilo udejanjanje trajnostno sonaravnega razvoja tudi $v$ drugih dejavnostih.

Kljub prevladujoči vlogi storitev v deležu BDP in zaposlovanju je industrija še vedno eden izmed ključnih dejavnikov razvojne strategije Zveze, ki ustvarja četrtino BDP (Towards Sustainability, 1993). Zaradi izkoriščanja naravnih virov, potrošnje energije, proizvodnje odpadkov in emisij, je evropska industrija še vedno med temeljnimi viri okoljske degradacije in izčrpavanja naravnih virov. Pri zagotavljanju optimalnih razmer za nadaljevanje kakovostne ekonomske rasti znotraj EZ je pomembno, da industrija Zveze odkrije obrazec trajnejšega ohranjenja gospodarske uspešnosti: v okviru nosilnosti okolja torej ohranjati ekonomsko rast. Številne nove čistejše tehnologije ne le zmanjšujejo potrošnjo energije in surovin, količino odpadkov in emisij, temveč obenem zmanjšujejo proizvodne stroške. Za uspešno industrijsko prenovo $v$ sonaravni smeri je obvezna sestavina okoljsko izobraževanje $v$ 
celotni proizvodni verigi, s posebnim poudarkom na raziskovalcih in proizvodnih inženirjih. Pri zadovoljevanju okoljskih zakonskih predpisov je zlasti v prvi fazi ekologizacije industrije in podjetij uvajanje tehnologij "na koncu pipe" izredno pomembno (Jettel, 1990). V to skupino pa se razen objektov za čiščenje zraka in vod uvrščajo sanacije starih okoljskih bremen, pa tudi sistemi reciklaže in objekti za ravnanje $\mathrm{z}$ odpadki.

Po mnenju Adensamove (1997), sodelavke avstrijskega ekološkega inštituta za uporabne raziskave okolja, nizke dajatve oziroma izdatki za varstvo okolja le kratkoročno pomagajo gospodarstvu, podjetjem. Pogosto se ukrepe politike okolja (ekološki davki, strogi emisijski standardi) prikazujejo kot "uničevalce" delovnih mest. Sodobne raziskave v Avstriji kažejo, da varstvo okolja v podjetjih ne pomeni uničevanja delovnih mest, temveč ravno nasprotno. V Nemčiji je na področju tehnik za okolje zaposleno 680000 prebivalcev, kar je $15 \%$ več kot v kemični industriji, v preteklosti ključni industrijski veji nemškega gospodarstva. L. 2000 naj bi na področju varstva okolja bilo več kot 1,1 milijona zaposlenih, v primeru stagnacije na okoljskem polju dejavnosti pa se bo število nezaposlenih v Nemčiji povečalo za 185000 (Oekoatlas Wien, 1995). Okoli 20 - 50 \% podjetij razvite Evrope je ob pričetku 90. let označevala ofenzivna ekološka usmerjenost kot dolgoročna sposobnost njihove finančne uspešnosti (Jettel, 1990). Takšna podjetja sprejemajo ukrepe za zmanjšanje obremenitve okolja, prostovoljno omejujejo oziroma izločajo uporabo nevarnih snovi, spreminjajo okolju neprijazno embalažo proizvodov in uvajajo reciklažo. V številnih evropskih državah se podjetja že pripravljajo za okoljske izzive 21. stoletja (Winter, 1994).

Obstajajo torej možnosti, da se še prisotna nasprotja med politiko zaposlovanja in okolja s pravilno izbiro ukrepov skoraj popolnoma izgladijo. Podrobne študije $v$ okviru EZ kažejo, da ukrepi za varstvo okolja bistveno prispevajo $h$ gospodarski rasti in zagotavljanju zaposlenosti. Naložbe $v$ varstvo okolja in pravilno zasnovani energijski davki lahko ustvarijo več delovnih mest kot tradicionalni ukrepi zaposlitvene politike države. Pred EZ je zahtevna naloga spremembe temeljnih pogojev tržnega gospodarstva tako, da bi bilo mogoče maksimalni ekonomski uspeh doseči zgolj s proizvodi in storitvami, ki so kar najbolj sprejemljivi za okolje. Okolju prijazno gospodarstvo pa se mora tudi ekonomsko izplačati, saj bodo šele $v$ tem primeru dinamične moči tržne konkurence delovale $v$ korist prenove okolja. $\mathrm{V}$ okviru optimalnega razmerja med preventivo in zdravljenjem okolja lahko nastanejo številna nova delovna mesta. V večini držav EZ se za varstvo okolja (pretežno še vedno za tehnologije "na koncu pipe") sredi 90. let namenja najmanj 1,5 - $2 \% \%$ BDP (Avstrija $-2,6 \%$ BDP; ZDA - 2,1 \% BDP 1. 1990), sredstva pa izvirajo iz javnega in privatnega sektorja. Kljub razmeroma visokemu deležu BDP za kontrolo okolja so stroški v primerjavi $\mathrm{z}$ merljivimi stroški degradacije okolja in naravnih virov razmeroma skromni, saj se okoljske škode v državah EZ ocenjujejo na 3 - 5 \% BDP.

Okoljske cilje $v$ petih ključnih gospodarskih dejavnostih (industrija, energetika, promet, kmetijstvo, turizem) bo možno doseči zgolj s spremembo osnovnih 
gospodarskih trendov. Strateški pristop za dosego okoljskih ciljev v temeljnih poljih EZ pa je naslednji (Towards Sustainability, 1993, s. 74):

1. industrija

a) integralna kontrola onesnaževanja (kataster emisij, ekorevizija, čistejše tehnologije, ekocertifikati);

b) zmanjšanje odpadkov (popis odpadkov, ekonomske iniciative, celovit sistem ravnanja, visoki okoljski predpisi glede odlaganja);

c) okoljsko prijaznejši proizvodi (okoljsko označevanje, višji kakovostni standardi, informacije potrošnikov, razlike v obdavčevanju);

2. energija

a) zmanjševanje energetskega onesnaževanja (posebni cilji glede $\mathrm{C} 02, \mathrm{SO} 2, \mathrm{NOx}$, varno odlaganje radioaktivnih odpadkov, ekonomske spodbude);

b) razvoj obnovljivih virov (raziskovanje, spodbude);

c) zmanjšanje potrošnje energije (ekonomske in finančne spodbude, izobraževanje in informiranje potrošnikov, zakonodajni instrumenti, prostovoljne iniciative);

3. promet

a) okolju prijaznejši avtomobili in goriva (strožji emisijski standardi za goriva, ekonomske in finančne spodbude, testiranje motorjev, manjša poraba goriva - $31 / 100$ $\mathrm{km}$;

b) racionalizacija prometne infrastrukture (mrežno načrtovanje, možnost izbire prometnega sredstva);

c) primernejše obnašanje voznikov (informiranje in izobraževanje, ekonomske in finančne spodbude, možnost izbire načina potovanja, prometno upravljanje)

4. kmetijstvo

a) sonaravno kmetovanje (ekstenzifikacija obdelave, zmanjšanje kemijskih vnosov, biološke kmetije, informiranje potrošnikov, ekonomske in finančne spodbude);

b) razvoj gozdarstva (sistematično pogozdovanje, zaščita pred požari, ravnovesno zasnovana količina poseka);

c) razvoj podeželja (kontrola rabe zemljišč, kmečki turizem);

5. turizem

a) sonaravni turizem (smotrno ravnanje s turističnimi odpadki, okolju prijaznejše oblike potovanja)

b) varovanje narave in okolja (naravna in kulturna dediščina, obalna območja);

c) širša izbira turističnih območij (kakovostne informacije, enakomernejša sezonska porazdelitev števila turistov). 


\section{INSTRUMENTI OKOLJSKE POLITIKE EZ}

Več kot 20 let so bile smernice prednostna zakonodajna oblika na področju okoljske politike EZ, kar je članicam omogočalo postopno prilagajanje državnih zakonodaj. Okoljska zakonodaja EZ in posameznih držav je do 90. let slonela predvsem na zakonskih instrumentih, ki so podpirali okoljski pristop "na koncu pipe", torej omejevanje vnosa emisij in odpadkov $v$ okolje, ne pa njihovega zmanjševanja proizvajanja. V ospredju je bil zakonodajni pristop, ki je podpiral in zakonsko opredelil točkasto zasnovane ukrepe zdravljenja okolja (Graedel - Allenby, 1995). V bodoče pa se naj bi okoljska zakonodaja EZ osredotočala na proizvode in storitve $\mathrm{v}$ celotni življenjski dobi, na preprečevanje vplivov tudi na bodoče generacije, ob upoštevanju nosilnih zmogljivosti regionalnih in globalnih okoljskih sistemov. Tako je bil $\vee$ okviru EZ že sprejet skupen program podeljevanja znaka okolju prijaznejših proizvodov. L. 1993 je bila sprejeta t.im. EMAS regulativa, s katero se $v$ okviru izvajanja 5. akcijskega okoljskega programa uvaja sistem prostovoljnega vodenja podjetij z vidika varovanja okolja (Predlog poročila o ..., 1996). Zakonodajne ukrepe posamičnega zdravljenja okolja naj bi zamenjala okoljska preventiva, zakonodajni sistemi okoljskega upravljanja, kjer naj bi bile določeni mejni pogoji proizvodnje in potrošnje.

Za udejanjanje sonaravnega razvoja na območju celotne Zveze pa so zelo pomembni tudi različni skladi EZ, ki so namenjeni tudi sonaravnemu regionalnemu razvoju in ekologizaciji gospodarskih in razvojnih politik. Temeljna reforma t.im. strukturnih skladov EZ je bila izvedena 1. $1988 \mathrm{v}$ smeri bistvenega povečanja sredstev skladov in njihovega osredotočenja na posamezne projekte. V obdobju 1987 - 1993 so se sredstva strukturnih skladov realno podvojila, v 1.1992 so predstavljala $27 \%$ skupnega proračuna Zveze. Znotraj Evropskega regionalnega sklada so se sredstva za t. im. okoljske projekte $v$ obdobju 1987 - 1991 povečala od 100 milijonov ECU na 700 milijonov ECU. Tudi v okviru Evropskega socialnega sklada (ESF) za podporo usposabljanju in ustvarjanju delovnih mest je del investicij namenjen za ekologizacijo podjetij. Za države Srednje - in Vzhodne Evrope obstaja temeljni program pomoči Phare, ki vključuje tudi Slovenijo. V prvih 5 letih (do konca 1. 1994), je 11 držav imelo na razpolago 4,3 milijard ECU, namenjenih prenosu znanja in spodbudam za investiranje. Phare podpira razvoj majhnih in srednjih podjetij, privatizacijo, infrastrukturne projekte, varstvo okolja, energijo, promet, telekomunikacije, kmetijske projekte, varstvo jedrskih reaktorjev itd, pa tudi socialne projekte (Draxler et al., 1996).

Večina strokovnjakov sodi, da bodo okoljsko zasnovani finančni mehanizmi postali osrednji mehanizmi okoljskopolitične strategije EZ druge polovice 90. let (Towards Sustainability, 1993). Trenutno je še vedno v ospredju klasičen regulativni pristop in določanje enotnih, vse bolj strogih emisijskih standardov. V naslednjem obdobju pa lahko pričakujemo večjo vlogo t.im. prenosnih onesnaževalnih dovoljenj, zlasti pa ekodavkov oziroma emisijskih dajatev. 
V državah EZ se krepi moč potrošnikov in nevladnih okoljskih organizacij, ki vplivajo na okoljsko podobo podjetja $v$ javnosti ter na ta način promovirajo okoljsko prijazne proizvodne procese in proizvode. Ekologizacijo podjetij podpirajo tudi zelene stranke, ki predlagajo tudi temeljito ekologizacijo celotnega davčnega sistema. Z javnim razvrščanjem podjetij na "čista" in "umazana" posredno izredno močno vplivajo na okoljsko politiko podjetij (Towards Sustainability, 1995). Potrošniki, zelene stranke in nevladne okoljske organizacije postajajo tako pomemben "instrument" spodbujanja hitrejše ekologizacije podjetij, proizvodov in storitev, saj posredno vplivajo na poslovno politiko in profitno (ne)uspešnost.

\section{SLOVENIJA IN OKOLJSKA POLITIKA EZ}

Slovenija je $\mathrm{v}$ zelo občutljivem prehodnem obdobju, ki zahteva pretehtane spremembe, prilagojene sodobnim evropskim razvojno - okoljskim procesom. Zaradi večplastne in po osamosvojitvi še okrepljene gospodarske, vrednostne in kulturne vpetosti $\mathrm{v}$ evropski prostor je njeno prilagajanje sodobnim okoljsko - razvojnim procesom eksistenčno pomembno in neizbežno. $\mathrm{V}$ primerjavi $\mathrm{z}$ večino držav $\mathrm{EZ}$ je njen izhodiščni ekonomski, socialni in okoljski položaj slabši. S sonaravnimi izzivi se srečuje z narodnim dohodkom na prebivalca, ki je približno dvakrat nižji, kot je povprečje EZ, $v$ času zaostrenih socialnih razmer in $\mathrm{z}$ bremenom številnih okoljskih problemov (zrak, voda, odpadki, zmanjševanje biološke raznovrstnosti). Značilna je dolgotrajnost posegov človeka $v$ slovenske pokrajinske ekosisteme (zlasti rečno kotlinskega) in izrazita povojna snovno - energetska obremenitev. Za celoten povojni družbeno - gospodarski razvoj je bila značilna zelo močna industrializacija, industrija pa je zelo dolgo bila najmočnejši gospodarski in zaposlitveni sektor (M.M. Klemenčič, 1993). Znižanje pomena trgov nekdanjih jugoslovanskih republik po 1 . 1990 je povzročilo gospodarske probleme, a tudi znižanje onesnaževanja nadpovprečno intenzivne proizvodnje in $\mathrm{s}$ tem znižanje onesnaževanja na enoto proizvoda (Radej, 1995).

Kljub nekaterim izboljšavam na področju onesnaženosti zraka so količine proizvedenih emisij, odpadnih vod in odpadkov na prebivalca še vedno bistveno večje, kot je evropsko povprečje. Med emisijami še vedno izstopajo velike količine SO2 (177 000 ton v 1. 1993), saj se je v obdobju 1980 - 1993 skupna količina SO2 zmanjšala le za $22 \%$. Tako Slovenija ni izpolnila določil prvega protokola o SO2, ki je predpisoval vsaj $30 \%$ zmanjšanje emisij SO2 do konca 1 . 1993. V primerjavi z 1 . 1987, ki je izhodiščno leto za NOx protokol, se je emisija NOx konec 1. 1993 povečala za 6,3 \% (Predlog poročila o ..., 1996). Ta protokol, ki ga Slovenija ni podpisala, terja do konca 1. 1994 zamrznitev emisij NOx na raven iz 1. 1987. Količine odpadnih voda so se $v$ zadnjih nekaj letih zmanjšale, vendar predvsem zaradi industrijskega upada, delež neprečiščenih odpadnih vod pa je nad evropskim povprečjem. Izboljšala se je 
kakovost površinskih vod in poslabšala kakovost nekaterih podtalnic in kraških izvirov. Količine odpadkov naraščajo; v Sloveniji nastaja letno že več kot $400 \mathrm{~kg}$ komunalnih odpadkov na prebivalca, skoraj vsi odpadki pa se neposredno odlagajo na sanitarno neprimerna odlagališča. Zavarovanega je približno 8 \% ozemlja, v Evropi pa se priporoča naravovarstvena zaščita petine ozemlja. Reševanje okoljskih problemov ni politično prednostno, saj se ne uvidi razvojna in socialna razsežnost primerne okoljske politike.

Zaradi zaostrenih gospodarskih in socialnih razmer se zgoščujejo politični pritiski, da Slovenija $v$ nasprotju s sodobnimi razvojnimi hotenji EZ izbere nesonaravno pot gospodarske prenove in politiko razvojnih osi, ki ni naklonjena enakomernejšemu regionalnemu razvoju slovenskih pokrajin. Opazen je precejšen zaostanek na zakonodajnem okoljskem področju (pomanjkanje sodobnih podzakonskih predpisov), Slovenija še nima izdelanega nacionalnega okoljskega načrta in nacionalne razvojne strategije, uvajanje ekonomskih instrumentov okoljske politike je zelo skromno in sektorsko. Izdelana je ekosocialna strategija kmetijstva, ki pa je zaradi skromnih državnih spodbud ni mogoče uresničiti. V obdobju pričakovanih pritiskov Evrope za gradnjo cestnih prometnih koridorjev zaradi pričakovanega povečanja cestnega tranzitnega prometa preko Slovenija še ni izdelana državna prometna strategija;zjema je le projekt izgradnje avtocest.

Slovenija bo prisiljena sprejeti tržne, socialne in okoljske standarde ter pogoje evropskega povezovanja, ne glede na dejstvo ali bo postala polnopravna članica EZ ali ne. Predpogoj je poznavanje in pospešeno prilagajanje sodobnim evropskim okoljskim in ostalim trendom, $v$ kolikor želimo čim bolj pripravljeni odgovoriti na zelo zahtevne in večplastne evropske in svetovne izzive. V kratkem času bi morali sprejeti sonaravno zasnovano državno razvojno strategijo in pospešiti zahtevno prilagajanje zakonodaje in drugih instrumentov okoljske politike evropskim trendom. $\mathrm{Na}$ področju varstva okolja je potrebno Zakon o varstvu okolja (sprejet 1. 1993) organsko dograditi s številnimi, sonaravno zasnovanimi podzakonskimi predpisi. Eden izmed temeljnih pogojev je povečanje proračunskih sredstev za varstvo okolja, regionalni razvoj in kmetijstvo. Sredi 90 . let namenja slovenski državni proračun varstvu okolja zelo skromen delež in sicer le še približno $0,6-0,7 \%$ BDP, razvite evropske države pa iz državnih sredstev najmanj 1 \% BDP, skupaj (javna in privatna sredstva) pa $1,5-2 \%$ BDP. Za prvo polovico 90 . let so bile značilne skromne okoljevarstvene naložbe; izjemo predstavlja ekološka sanacija Te Šoštanj (blok 4 in 5), ki se uresničuje tudi s pomočjo sosednje Avstrije. V prihodnjih letih bi se morala okoljevarstvena proračunska sredstva občutno povečati, kasneje pa bi morala postati sredstva podjetij in prebivalstva (privatna sredstva) osnovni vir sredstev varstva okolja (Radej, 1995). Radej (1995) skupne stroške onesnaženosti okolja v Sloveniji ocenjuje na $4-6 \%$ BDP, torej nekajkrat več kot znašajo sredstva za okoljske sanacije. Oblikovanje Ekološko - razvojnega sklada je spodbudilo najemanje ugodnejših posojil za naložbe na področju varstva okolja (Predlog poročila o ..., 1996) Državna sredstva za spodbujanje enakomernejšega regionalnega razvoja so se $v$ 90. letih znižala na pičlih $0,1 \%$ BDP, $v$ državah EZ pa povečala na $0,4 \%$ BDP. Proces širjenja območij 
koncentracije prebivalstva spremlja tudi širitev območja prebivalstvenega praznenja, $v$ obeh primerih na račun prebivalstveno prehodnih območij ( V. Klemenčič, 1995). V obdobju 1981 - 1991 je število prebivalcev Slovenije nazadovalo za več kot 2,5\% na približno četrtini površja Slovenije (26\%), podeželje pa zgublja svoje značilnosti (Gosar, 1995). Razvojne razlike med slovenskimi regijami se po ugotovitvah Kukarjeve (1995) in Ravbarja (1995) še vedno povečujejo, zakona o regionalnem razvoju pa državni zbor po dveh letih ni sprejel. Zaradi spremenjenih domačih razmer in reforme evropske politike regionalnega razvoja bo potreben prenove in dopolnil; $v$ pripravi je tudi nov prostorski plan države.

Do 1. 2000 se pričakujejo pomembne strukturne spremembe slovenskega gospodarstva, ki bodo vplivale tudi na stanje okolja. Povečeval se naj bi delež storitvenih dejavnosti na račun postopnega zmanjšanja deleža kmetijstva in industrije, vendar naj bi bolj produktivna industrija ohranila izjemno pomembno zaposlitveno in razvojnotehnološko vlogo. Po mnenju oblikovalcev Strategije povečevanja konkurenčne sposobnosti slovenske industrije (1996) bo Slovenija do 1. 2000 brez izboljšanja okoljske produktivnosti zelo težko ohranila celo sedanje stanje okolja in hkrati izpolnila prevzete mednarodne okoljske obveznosti in priporočila. Ocenjeno povečanje industrijskega onesnaževanja pa naj bi bilo nižje od pričakovanega porasta proizvodnje, torej se naj bi onesnaževanje na enoto proizvodnje znižalo. V večini slovenskih podjetjih je $\mathrm{v}$ primerjavi s podjetji članic EZ bistveno manj prisotna zavestna okoljska politika vodenja in poslovanja. Na vložek $v$ varstvo okolja podjetniki gledajo predvsem kot na strošek in ne kot dolgoročno naložbo $\mathrm{v}$ okolju prijazen izdelek. Okoljski pristop $v$ poslovanju podjetij bi morala v večji meri spodbujati vlada in organizirati raznovrstno (zakonsko, davčno, ekonomske spodbude, podeljevanje znaka za okolje) podporo podjetjem, ki proizvajajo po načelih sonaravnega razvoja.

Zaradi gospodarske sestave, tehnološkega zaostanka, socialne krize in več desetletij trajajočega okoljskega izčrpavanja Slovenije bo njeno prilagajanje sodobnim sonaravnim evropskim trendom skrajno zahtevno (Plut, 1995). Na poti prilagajanja strateškemu pristopu 5. akcijskega okoljskega programa in pokrajinsko - ekološkim, geografskim stalnicam in spremenljivkam Slovenije, bi morale biti poudarjene naslednje okoljske in razvojne usmeritve:

- pospešena sanacija največjih onesnaževalcev zraka, zmanjševanje količin odpadne vode in večji delež čiščenja, uveljavljanje gospodarjenja $\mathrm{z}$ odpadki s poudarkom na zmanjševanju proizvajanja odpadkov in uvajanje njihovega vračanja ter večkratne uporabe;

- tehnološka posodobitev industrije, s poudarkom na zmanjševanju snovno energijskih tokov $\mathrm{v}$ proizvodnji in potrošnji ter povečevanje deleža uporabe obnovljivih in decentraliziranih energetskih virov;

- upoštevanje nosilnosti okolja kot temeljnega omejitvenega dejavnika pri nadaljnjih posegih $\mathrm{v}$ okolje in prostor;

- povečevanje naravovarstvenih območij, zlasti tistih, katerih varstveni režim bi v večjem delu omogočil sonaravno gospodarjenje; 
- zmanjševanje razpršene stanovanjske gradnje ob hkratnemu spodbujanju ohranjanja obstoječega tipa poselitve in deleža kulturne pokrajine;

- sonaraven in policentričen regionalni razvoj z opredelitvijo ciljnih območij na osnovi kriterijev EZ, s prepoznavanjem in plačevanjem večnamenske vloge sonaravnega kmetijstva (n.pr. povečevanje bioloških kmetij in pridelave kakovostne, zdrave hrane) ter večje uporabe regionalnih virov;

- posodobitev cestnega in ostalega infrastrukturnega omrežja $s$ prednostim upoštevanjem razvojnih potreb slovenskih pokrajin in omejevanje tranzitnega cestnega prometa glede na emisijsko nosilnost območij ob prometnicah.

Evropske izkušnje kažejo, da je za ekologizacijo gospodarstva zlasti v začetku bistvena načrtna okoljska in regionalna politika države (večja proračunska sredstva, ekologizacija celotnega gospodarstva, primerni okoljski in regionalni instrumenti, strožja okoljska zakonadaja, uvajanje ekonomskih instrumentov), stopnja okoljske osveščenosti prebivalcev in zadovoljiv materialni standard ter sposobnost podjetij, da sledijo sonaravnemu trendu evropske industrije. Zaradi razvojnega zaostanka bo proces usklajevanja s sodobnimi okoljskimi, regionalnimi in kmetijskimi evropskimi trendi zelo težaven in tudi proračunsko zahteven. V pričakovanem pričetku temeljite in kompleksne analize posledic možnega polnopravnega članstva $\mathrm{v}$ EZ bo potrebno posebno pozornost nameniti problematiki kmetijstva (slabi naravni pogoji, majhna povprečna velikost kmetij, razparceliranost), tranzitnega prometa (kraško površje, gorske doline, kmetijske površine, naravovarstvena območja), odprtju trga nepremičnin (nakup zemljišč) tujcem, ekologizaciji gospodarstva in regionalnim razlikam. Avstrija je 8 let pred referendumsko odločitvijo o vstopu v EZ pričela s številnimi strokovnimi analizami o posledicah polnopravnega članstva na vseh družbenih poljih. Sredi 90. let pri nas še vedno ni dovolj prisotno spoznanje o večplastni prednosti hitrega približevanja sonaravni paradigmi kot najbolj verjetni vodilni paradigmi 21 . stoletja. 


\section{LITERATURA}

- Adensam H., 1997: Varstvo okolja ustvarja delovna mesta. V: Vestnik (2.1. 1997) - evropska priloga, str. 24 - 25, Murska Sobota.

- Atlas of the Environment, 1990, New York.

- Draxler P., Schramm J., Radoczky I., Petsche M., 1996: ABC der EU Foerderungen. Wien.

- Europe's Environment (The Dobriš Assessment), 1995. European Environmental Agency, Copenhagen.

- Gemeinschaftsrecht im Bereich des Umweltschutzes - Band 1, 1996, EGKS - EG EAG, Bruessel - Luksemburg.

- Gosar L., 1995: Širši vidiki gospodarskega razvoja. V: Strategija gospodarskega razvoja Slovenije (Prostor, okolje, socialna varnost), Zavod RS za makroekonomske analiza in razvoj, str.75 - 80, Ljubljana.

- Graedel T., Allenby B., 1995: Industrial Ecology, New Yersey.

- Jettel C., 1990: Umweltmassnahmen und Oekologieorientirung in der Europaeischen Gememinschaft und in Oestereich. Scriftenreihe des Insituts fuer Wirtschaftswissenschaften an der Rechtswissenschaftlichen Fakultaet der Universitaet Salzburg, Band 3, Regensburg.

- Klemenčič M.M., 1993: Družbenogospodarski razvoj obmejnih območij v Sloveniji. Dela 10, str. 127 - 134, Ljubljana.

- Klemenčič V., 1995: Prostorska diferenciacija Republike Slovenije po demografskih procesih in demografskih strukturah. V: Gradivo strokovnega posveta DS RS, str. 24 - 29, Ljubljana.

- Kukar S., 1995: Regionalni razvoj v Sloveniji. V: Strategija gospodarskega razvoja Slovenije (Prostor, okolje, socialna varnost), Zavod RS za makroekonomske analize in razvoj, str. 7 - 22, Ljubljana.

- Oesterreichische Raumordnungskonferenz - Siebenter Raumordnungsbereicht, 1993. Geschaeftsstelle der Oesterreichischen Raumordnungkonferenz (OEROK), Wien.

- Plut D., 1995: Osnovne pokrajinsko - ekološke prvine okoljevarstvene strategije Slovenije. V: Strategija gospodarskega razvoja Slovenije (Prostor, okolje, socialna varnost), Zavod RS za makroekonomske analize in razvoj, str. 71 - 74, Ljubljana.

- Predlog poročila o stanju okolja 1995, 1996, Poročevalec DZ/št. 6/1, Ljubljana.

- Radej B., 1995: Okoljevarstveno ovrednotenje izvozno podprtega modela razvoja. V: Strategija gospodarskega razvoja (Prostor, okolje, socialna varnost), Zavod RS za makroekonomske analize in razvoj, str. 63 - 69; Ljubljana.

- Ravbar M., 1995: Regionalnogeografski vidiki demografske politike v luči sodobnih sprememb v poselitvi Slovenije. V: Gradivo strokovnega posveta DS RS, str. 30 - 39, Ljubljana. 
- Strategija povečevanja konkurenčne sposobnosti slovenske industrije. 1996, Ministrstvo za gospodarske dejavnosti, Ljubljana.

- Towards Sustainability 1993, Commmision of the European Communities, Luxembourg.

- Winter G., 1994: Okolju prijazno podjetje (prevod), Inštitut za ekološki management (Drevo), Ljubljana.

\section{SLOVENIA AND THE FORMATION OF SUSTAINABLE DEVELOPMENTAL STRATEGY OF THE EUROPEAN UNION}

\section{Summary}

The European Union (EU) has to face the problems of unemployment, the crisis of the current social security system, certain developmental lags behind the most innovative developmental focuses in the world. Regional differences increase, agriculture has problems with agricultural surplusses, and numerous environmental problems are present. Owing to the intertwining of lines-of-force from the economic, social and environmental fields, the awareness has developed that it is necessary to elaborate and effectuate a new European developmental model. Changes in the structural developmental funds of the EU, contemporary measures for determining developmentally weak regions, a new common agricultural policy and the $5^{\text {th }}$ active environmental programme are the components of the European developmental strategy which is coming into existence. The active agricultural, regional and environmental programmes of the EU proceed from the principles of sustainable development which restricts market economy by means of environmental and social corrections.

The $5^{\text {th }}$ active environmental programme of the EU (1993-2000) represents a consistently planned programme for effectuating sustainable development by means of clearly defined environmental aims in five basic economic spheres: manufacturing industry, energy production and distribution, transport, agriculture, and tourism. The recentmost investigations show that the integration of environmental principles into European economy would be an opportunity for employment and economy. In the mid-90's, the legislative instruments are still the basic measure of the common EU environmental policy which must be incorporated into the legislations of all the members of the Union. Particularly in the second half of the 80's and in the 90 's, the emission standards have become ever more rigorous, while the process of adapting to the EU measures has been shortened. Financial environmental instruments have also gradually gained importance and, according to the experts' opinion, they will become the central instrument of effectuating the EU sustainable development in the future. 
Slovenia has to face the environmentally rigorous developmental strategy of the EU in the time of demanding transition, in the grip of economic, environmental and social problems. Slovenia is intensely integrated into European space with the economic, transport, cultural and other links. Therefore, it is urgent to adapt Slovenian regulations and developmental strategy to the environmental, regional and agricultural directives of the EU, notwithstanding the fact whether or not Slovenia would become a full member of the EU. The experiences of Austria show that it is necessary to start adapting to the EU directives and policy approximately 10 years before the possible membership. At the UN World Conference on Environment and Development of 1992 in Rio de Janeiro, Slovenia signed the documents upholding the introduction of the principles of sustainable development; yet, in practice, it adheres to them only partially and by sectors. The process of coordinating Slovenian environmental standards with the European ones is already rather delayed. Although the adopted ecosocial strategy of Slovenian agriculture is quite in accord with the principles of the common agricultural EU policy, it is the budget support which is markedly lower, and the same also applies to the regional policy.

Thus, the "European image" of Slovenian environmental policy is also the developmental necessity and opportunity; on the other hand, the basic considerations about the negative consequences of the possible membership in the EU are particularly concerning the following spheres: agriculture, transport (transit) and the opening of real-estate market to foreigners (the possibility of land purchase). 